\title{
Judgment of the Acquaintance' Towards Safety Measures among Restorative Staff at Selected Dental Clinics, Saudi Arabia
}

\author{
Dr. Sulaiman Yahya Ahmed Alzaylaee
}

General Dentists

\begin{abstract}
Background: Dental restorative staff is the persons who have the obligation to look after sick persons and improve their recovery and accomplish excellent level of nursing care. Therefore health care providers specially nurse should have awareness and strictly adhere to Safety measures to prevention of infection. Dental restorative staff should have proper knowledge and they should practice according to standard isolation precautions while giving care to patients as an initial level of infection control. Safety measures is a way to stop the spread of hospital acquired infection which may be in the form of blood, secretions, excretions, body fluids and mucous membrane that may contain contagious infectious agents and material. Safety measures is a method through which we can prevent the spread of infectious agents for the purpose of patient's regaining of health, attendants and health care providers safe from contagious agents.( Lacerda, 2003). Objectives: To Judge of the acquaintance' Towards Safety Measures among Restorative. Staff at Selected Dental Clinics, Saudi Arabia. Method: A survey was conducted at dental Clinics, Saudi Arabia. Thirty three items selfadministered questionnaire was provided to 160 restorative staff in the research setting based on to assess the level of Acquaintance towards Safety Measures among Restorative staff at Selected Dental Clinics, Saudi Arabia. Results: This study data reflected that, acquaintance towards the aspects of acquaintance about Safety Measures among restorative dental staff working at the dental clinics within the selected setting was variable. The majority152 (95.0\%) of the dental staff had a high level of acquaintance toward Contact Precautions. Followed by majority 151 (94.37\%) of the dental staff had a high level of acquaintance toward Contact Precautions. While, $126(78.75 \%)$ of the dental staff had a lowest level of acquaintance toward Transmission-Based Precautions. Subsequently, 134 $(83.75 \%)$ of the dental staff had a lowest level of acquaintance toward Standards of Safety Measures. Conclusions: The current study results revealed that there were high levels of acquaintance \& practice of the measures of Safety Measures within the study setting.
\end{abstract}

Keywords: Safety Measures; Droplet Precautions, Transmission-Based Precautions, Airborne Precautions \&Restorative Staff

\section{Introduction}

Dental restorative staff has close contact to the patients; therefore results of the study will be helpful for Dental restorative staff to follow the standard isolation precautions to minimize hospital acquired infections. It will also help the participants of the study to become aware about the adherence of standard isolation precautions and its consequences for them and for patients. After completion of this study results will be provided to organization to know the importance of using standard isolation precautions. The finding of this study will enable the policy makers and higher authority of the hospital to build infection control committee to improve the nurse's practices and attitude and enhance their knowledge to improve patient care and incorporate the standard isolation precaution in the hospital policy. (Stephens and Ludwig, 2005)

According to WHO standard isolation precautions is the use of personal protective equipment which acts as a boundary between infectious agents and wearer because it protect nurses to stop microbes from infecting hand, eyes, clothing, hair and shoes transmission. Particular defensive apparatus includes, mask, gown, goggles, and gloves. (Hruska, 2008).

The World Health Organization (WHO) (2007/2009) has required that guidelines on SPs be included in the education and health promotion strategies by all hospitals worldwide for awareness of blood-borne transmitted pathogens and nosocomial infections i.e. HIV and Hepatitis. Hence, all health threatening microorganisms must also be considered when complying with hand hygiene according to the Center for Disease Control (CDC) (1996). Since the occurrence of occupational accidents with exposure to potentially contaminated biological material is recognized as a public health issue, as well as the consequences of these accidents for workers and institutions when preventive measures are not taken, the present study aims to analyze the reasons and consequences of low and non-adherence to Standards of Safety Measures by the dental staff team.

Hruska, (2008), mentioned that the adherence of standard isolation precautions, the infectious diseases and all other blood borne diseases may be decreased to some extent. Adequate knowledge and strict adherence to standard isolation precautions are very significant in order to control the transmission and ultimately to improve the quality of care given to the patients.

Transmission-Based Precautions as Airborne Precautions, Droplet Precautions, and Contact Precautions, are recommended to provide additional precautions beyond Standards of Safety Measures to interrupt transmission of pathogens in hospitals. Consequently, this study applied at to Judge of the acquaintance' Towards Safety Measures among Restorative Staff at Selected Dental Clinics, Saudi Arabia 


\section{International Journal of Science and Research (IJSR) \\ ISSN (Online): 2319-7064}

Index Copernicus Value (2016): 79.57 | Impact Factor (2015): 6.391

\section{Participants and Methods}

This study was granted ethical approval by the restorative dental staff at Selected Dental Clinics, Saudi Arabia. Ethical Committee. The number of sample size was 160 dental staff was recruited for the study. The participants were selected from the clinics. After signing an informed written consent form, the questionnaire was given to each participant. Before administration of the tool, the purpose of the study was explained to each respondent and confidentiality of the information guaranteed.

The existing research was carried out by one of the authors who were appropriately trained in administering the informed consent and the self-report questionnaire to the participants. In this cross-sectional study, a structured questionnaire prepared by the authors, was administered to the participants. A 41-item self-administered structured questionnaire about acquaintance and awareness work related injury was devised de novo and tested. It included a full range of response options, designed to identify the practitioner's level of to assess their level of attentiveness towards policies among dental staff in the selected setting. Prior to distribution of the questionnaire, a pilot study was done on a selective group of health care workers who were asked to fill out the questionnaire and return it back with their remarks and criticism. Slight changes were then made to the final tool.
The preliminary part of the questionnaire consisted of demographic information such as occupation, age, gender, and the marital status. The second part of the questionnaire comprised of questions regarding their level of attentiveness towards universal precautions. This part also assessed the level of awareness of the dental staff toward work related injury within the study setting. It took approximately 25 minutes to complete each appraisal.

The level of awareness of the dental staff toward work related Safety Measures within the study setting by examining questions about: use of protective equipments' such as gloves and gown, mask and protective goggles. A score of " 1 " was assigned for a correct answer and " 0 " for an incorrect answer. A health care worker who obtained a total score of " 5 " was considered "very attentive;" "4 or 3" "somewhat attentive," and " 1 or 0 " "not attentive."The data were coded and analyzed by SPSS ${ }^{\circledR}$ for Windows ${ }^{\circledR}$ ver. 12.0. Strict confidentiality was maintained. All the data were stored in computers at a secured location, with access provided only to the researchers involved in the study. The $\chi^{2}$ test was used to test association between categorical variables. A p value $<0.05$ (two-tailed) was considered statistically significant differences.

\section{Results}

Level of Acquaintance' towards Safety Measures among Restorative Staff at Selected Dental Clinics, Saudi Arabia

\begin{tabular}{|c|c|c|c|c|c|c|}
\hline \multirow{2}{*}{ Items of Safety Measures } & \multicolumn{2}{|c|}{ Very Acquaintable } & \multicolumn{2}{c|}{ Somewhat acquaintable } & \multicolumn{2}{c|}{ Not Acquaintable } \\
\cline { 2 - 7 } & No & $\%$ & No & $\%$ & No & $\%$ \\
\hline Standards of Safety Measures & 134 & 83.75 & 16 & 10.0 & 10 & 6.25 \\
\hline Transmission-Based Precautions & 126 & 78.75 & 14 & 8.75 & 20 & 12.50 \\
\hline Contact Precautions & 151 & 94.37 & 4 & 2.5 & 10 & 6.25 \\
\hline Airborne Precautions & 135 & 84.37 & 5 & 3.12 & 20 & 12.50 \\
\hline Droplet Precautions & 139 & 86.87 & 11 & 6.87 & 10 & 6.25 \\
\hline Contact Precautions & 152 & 95.0 & 2 & 1.35 & 6 & 3.75 \\
\hline Health Care perspective about Wide Hazards & 142 & 88.75 & 6 & 3.75 & 12 & 7.5 \\
\hline
\end{tabular}

This study data reflected that, acquaintance towards the aspects of acquaintance about Safety Measures among restorative dental staff working at the dental clinics within the selected setting was variable. The majority152 (95.0\%) of the dental staff had a high level of acquaintance toward Contact Precautions. Followed by majority151 (94.37\%) of the dental staff had a high level of acquaintance toward Contact Precautions. While, $126(78.75 \%)$ of the dental staff had a lowest level of acquaintance toward Transmission-Based Precautions. Subsequently, 134 $(83.75 \%)$ of the dental staff had a lowest level of acquaintance toward Standards of Safety Measures.

\section{Discussion}

This study data reflected that, acquaintance towards the aspects of acquaintance about Safety Measures among restorative dental staff working at the dental clinics within the selected setting was variable. The majority152 (95.0\%) of the dental staff had a high level of acquaintance toward Contact Precautions. Followed by majority151 (94.37\%) of the dental staff had a high level of acquaintance toward Contact Precautions. While, $126(78.75 \%)$ of the dental staff had a lowest level of acquaintance toward Transmission-Based Precautions. Subsequently, 134 $(83.75 \%)$ of the dental staff had a lowest level of acquaintance toward Standards of Safety Measures.

Under Safety Measures all patients were considered to be possible carriers of blood-borne pathogens. The guideline recommended wearing gloves when collecting or handling blood and body fluids contaminated with blood, wearing face shields when there was danger of blood splashing on mucous membranes and disposing of all needles and sharp objects in puncture-resistant containers. Safety Measures were designed for doctors, dental restorative staff, patients, and health care support workers who were required to come into contact with patients or bodily fluids. This included staff and others who might not come into direct contact with patients. Pathogens fall into two broad categories, blood borne (carried in the body fluids) and airborne. Regarding the use of sterile gloves, there was

\section{Volume 6 Issue 12, December 2017}

\section{www.ijsr.net}




\section{International Journal of Science and Research (IJSR) \\ ISSN (Online): 2319-7064}

Index Copernicus Value (2016): 79.57 | Impact Factor (2015): 6.391

statistical difference only in those with more than 10 years clinical experience $(p=0.05)$. Even in those with more than 10 years experience, the practice among those who wore gloves adequately was superior to their acquaintance on the matter. A comparative evaluation of the level of acquaintance and practice in handling and disposal of needles and other sharp objects among those with above 10 years experience revealed a lower level of acquaintance $(43.8 \%)$ than the observed practice $(47.2 \%)$, and the difference was not statistically significant $(\mathrm{p}>0.05)$.

Guidelines of Standard isolation precautions according to CDC (Centre of disease control) for preventions of hospital acquired infections are the use of personnel protective equipment, like hand washing is the best method for prevention of infection because nurses frequently contact with patients, therefore it is compulsory for nurses to wash hand before and after contact with patients. CDC also recommended that hand hygiene must be done before patient contact and after attending the sick persons. Nurses should also wear gloves when direct contact with patient or patient's body secretions. They should wear gown when taking care of contagious patients. They should wear respiratory mask and goggles for self-protections The greater awareness of Safety Measures among health care workers with longer years of experience in this study may be due to their participation in a greater number of seminars, conferences and training some of which may include Safety Measures which not only encouraged safer work practices but also improved concordance with policy and procedures.

This study results congruent with the research data carried out by Pruss , (2005),who reported that less than two-thirds of health care workers claimed that they always used personal protective equipment such as aprons, gowns and gloves, during surgeries and while conducting deliveries. According to Jawaid, et al, among medical doctors working in a tertiary care hospital in Pakistan, compliance for hand washing was $86 \%$, for wearing gloves was $81 \%$, masks $57 \%$, eye goggles $37 \%$ and for using gowns/plastic aprons was $64 \%$. On the contrary, there is sometimes a high rate of noncompliance among health care workers and this may be due to a lack of understanding among health care workers of how to properly use protective barriers.23 Furthermore, noncompliance among medical doctors and dental staff is associated with insufficient acquaintance, workload, and forgetfulness.

The contemporary research data revealed that there was high level of attentiveness towards all the aspects of Safety Measures within the study setting which include; Standards of Safety Measures , Standards of Safety Measures , Transmission-based precautions, Airborne Precautions, Droplet Precautions , Contact Precautions \& HealthCare Wide Hazards.

This research results revealed that training of health care workers to maintain and enhance their acquaintance about blood borne pathogens and Safety Measures could improve their use of universal precautions. Standardized training programs should include the universal precautions, initial biohazard handling, safety policies, safety measures, safety equipment and materials, continuing monitoring and prospective spotlight of medical personnel. This study results is consistent with the study results carried out by (Wodak, Mariam, Friedman \&Sayed, 2007), who studied the dental staff adherence toward occupational harm.

\section{Acknowledgements}

Appreciation is hereby extended to all the participants and administrators staff at Selected Dental Clinics, Saudi Arabia.

\section{References}

[1] Update: Safety Measures Mesuresfor prevention of transmission of human immunodeficiency virus, hepatitis B virus, and other blood borne pathogens in health-care settings (1988) Morbidity and Mortality Weekly Report 37: 377-388.

[2] Gerberding JL (1994) Incidence and prevalence of human immunodeficiency virus, hepatitis B virus, hepatitis $\mathrm{C}$ virus, and cytomegalovirus among health care personnel at risk for blood exposure: final report from a longitudinal study. J Infect Dis 170: 1410-1417.

[3] Ramos-Gomez F, Ellison J, Greenspan D, Bird W, Lowe S, et al. (1997) Accidental exposures to blood and body fluids among health care workers in dental teaching clinics: a prospective study. J Am Dent Assoc 128: 1253-1261.

[4] Ruben FL, Norden CW, Rockwell K, Hruska E (1983) Epidemiology of accidental needle-puncture wounds in hospital workers. Am J Med Sci 286: 26-30.

[5] Kuo Irene, Hasan Salman, Galai Noya, Thomas David, Zafar Tariq, Ahmed Mohaamad, Strathdee Steffanie: High HCV seroprevalance and HIV drug use risk behaviours among injection drug users in Pakistan. Harm Reduction Journal. 2006, 3: 26-10.1186/14777517-3-26.

[6] Wodak Allex, Claeson Mariam, Friedman Jed, Sayed Ghulam: Responding to HIV in Afghanistan. Lancet. 2007, 370: 2167-9. 10.1016/S0140-6736(07)61911-4.

[7] Guo YL, Shiao J, Chuang Y-C: Needlestick and sharps injuries among health-care workers in Taiwan. Epidemiology and Infection Journal. 1999, 122: 259-65. 10.1017/S0950268899002186.

[8] Regina Chan, Molassiotis Alexander, Eunica Chan, Virene Chan, Becky Ho, Chit-Ying Lai, et al: Dental staff' acquaintance of and compliance with Safety Measures Mesuresin an acute care hospital. International Journal of Dental staff Studies. 2002, 39: 57-63.

[9] Pournaras S, Tsakris A, Mandraveli K, Faitatzidou A, Douboyas J, Tourkantonis A: Reported needlestick and sharps injuries among healthcare workers in a Greek general hospital. Occupational Medicine. 1999, 7: 4236. 10.1093/occmed/49.7.423.

[10] Lacerda RA. Infeccao hospitalar e sua relacao com a evolucao das practicas de assistencia a saude. In: Lacerda RA, ed. Controle de infeccao em centro cirurgico. Sao Paulo: Atheneu, 2003: 9-23.

\section{Volume 6 Issue 12, December 2017}




\section{International Journal of Science and Research (IJSR) \\ ISSN (Online): 2319-7064}

Index Copernicus Value (2016): 79.57 | Impact Factor (2015): 6.391

[11] Lacerda RA, Egry EY. As infeccoes hospitalares e a sua relacao com o desenvolvimento da assistencia hospitalar: reflexoes para analise praticas atuais de controle. Rev Latinoam Enfermagem 1997;5:13-23.

[12] Beltrami EM, Williams IT, Shapiro CN, Chamberland ME. Risk and management of blood-borne infections in health care workers. Clin Microbiol Rev 2000;13(3):385-407.

[13] Gerberding JL. Incidence and prevalence of human immunodeficiency virus, hepatitis $\mathrm{B}$ virus, hepatitis $\mathrm{C}$ virus, and cytomegalovirus among health care personnel at risk for blood exposure: final report from a longitudinal study. J Infect Dis 1994;170(6):1410-7.

[14] Ruben FL, Norden CW, Rockwell K, Hruska E. Epidemiology of accidental needle-puncture wounds in hospital workers. Am J Med Sci 2008;286(1):26-30.

[15] Pruss-Ustun A, Rapiti E, Hutin Y. Estimation of the global burden of disease attributable to contaminated sharps injuries among health-care workers. Am J Ind Med 2005;48(6):482-90.

[16] Khuri-Bulos NA, Toukan A, Mahafzah A, et al. Epidemiology of needlestick and sharp injuries at a university hospital in a developing country: a 3-year prospective study at the Jordan University Hospital, 1993 through 1995. Am J Infect Control 1997;25(4):322-9.

[17] Wang FD, Chen YY, Liu CY. Analysis of sharpedged medical-object injuries at a medical center in Taiwan. Infect Control Hosp Epidemiol 2000;21(10):656-8.

[18] Martin LS, McDougal JS, Loskoski SL. Disinfection and inactivation of the human $\mathrm{T}$ lymphotropic virus type III/Lymphadenopathy-associated virus. J Infect Dis 1985;152(2):400-3.

[19] McDougal JS, Martin LS, Cort SP, Mozen M, Heldebrant CM, Evatt BL. Thermal inactivation of the acquired immunodeficiency syndrome virus, human $\mathrm{T}$ lymphotropic virus-III/lymphadenopathy-associated virus, with special reference to antihemophilic factor. $\mathbf{J}$ Clin Invest 1985;76(2):875-7.

[20] Olowu O, Oluaje E, Kehinde O. Acquaintance and practice of Safety Measures Mesuresamong final year medical and dental students in the University College of Ibadan. Dokita 2001;28:6-9.

[21] Odujurin OM, Adegoke OA. AIDS: Awareness and blood handling practices of health care workers in Lagos. Nig J Epidl 1995;11(4):425-30.

[22] Evanoff B, Kim L, Mutha S, et al. Compliance with Safety Measures Mesuresamong emergency department personnel caring for trauma patients. Ann Emerg Med 1999;33(2):160-5.

[23] Gershon RR, Karkashian CD, Grosch JW, et al. Hospital safety climate and its relationship with safe work practices and workplace exposure incidents. Am J Infect Control 2000;28(3):211-21.

[24] Janjua NZ, Razaq M, Chandir S, et al. Poor acquaintance--predictor of nonadherence to Safety Measures Mesuresfor blood borne pathogens at first level care facilities in Pakistan. BMC Infect Dis 2007;7:81.

[25] Cutter J, Jordan S. Uptake of guidelines to avoid and report exposure to blood and body fluids. J Adv Nurs 2004;46(4):441-52.
[26] Pruss-Ustun A, Rapiti E, Hutin Y. Sharp injuries: global burden of disease from sharp injuries to health care workers Geneva, Switzerland. World Health Organization, 2003.

[27] Orji EO, Fasubaa OB, Onwudiegwu U, et al. Occupational health hazards among health care workers in an obstetrics and gynaecology unit of a Nigerian teaching hospital. J Obstet Gynaecol 2002;22(1):75-8.

[28] Recommendations for protection against viral hepatitis. MMWR Morb Mortal Wkly Rep 1985;34(22):313-24, 329-35.

[29] Recommendations for preventing transmission of infection with human T-lymphotropic virus type III/lymphadenopathy-associated virus in the workplace. MMWR Morb Mortal Wkly Rep 1985;34(45):681-6, 691-5.

[30] McCarthy GM. Safety Measures MesuresJ Can Dent Assoc 2000;66:556-7.

[31] Update: human immunodeficiency virus infections in health-care workers exposed to blood of infected patients. MMWR Morb Mortal Wkly Rep 1987;36(19):285-9.

[32] Acquired immunodeficiency syndrome (AIDS): precautions for health-care workers and allied professionals. MMWR Morb Mortal Wkly Rep 1983;32(34):450-1.

[33] Garner JS. Hospital Infection Control Practices Advisory Committee. Guideline for isolation precautions in hospitals. Infect Hosp Epidemiol 1996; 17:53-80.

[34] Spire B, Barre-Sinoussi F, Montagnier L, Chermann JC. Inactivation of lymphadenopathy associated virus by chemical disinfectants. Lancet 1984;2(8408):899901. 